\title{
Effect of iron and protein deficiency on the expulsion of Nippostrongylus brasiliensis from the small intestine of the rat
}

\author{
T. D. BOLIN, A. E. DAVIS, A. G. CUMMINS, V. M. DUNCOMBE, AND \\ J. D. KELLY
}

From the University of New South Wales, Gastrointestinal Unit, Prince of Wales Hospital, and Department of Veterinary Pathology, University of Sydney, New South Wales, Australia

SUMMARY The relationship between iron deficiency and protein deficiency and infestation of the rat with the nematode Nippostrongylus brasiliensis was investigated. There was a significant delay in the expulsion of $N$. brasiliensis from the small intestine of both iron deficient and protein deficient animals and those with a combined deficiency of iron and protein. Iron repletion returned the time of worm expulsion to normal and this would appear to be related to iron deficiency per se rather than to anaemia. Antibody initiated damage to worms was normal in the control animals and in animals with nutritional deficiencies. This suggests that the defect in worm expulsion occurs either in the cell-mediated immune system or in one of the other mediators of expulsion. Extrapolation to the human situation has important therapeutic implications in that iron and protein deficiency may play an important role in the perpetuation of helminth infestations. Thus, to be successful antihelminth therapy should be accompanied by iron and protein supplementation.

Controversy exists regarding the relationship between tissue iron levels and resistance to infection. There is some evidence in man that iron deficiency protects against bacterial infections (Masawe et al., 1974). On the other hand, Masawe et al. (1974) showed that there was an increased incidence of malarial attacks after iron therapy and other workers (Caroline et al., 1969; Fletcher and Goldstein, 1970) also demonstrated an increase in infection after iron therapy.

There is less controversy surrounding the relationship between protein deficiency and increased susceptibility to infection and, in fact, the synergystic interaction of infection and malnutrition is well recognised on the basis of clinical observations and epidemiological data (Scrimshaw et al., 1968).

The preceding observations are related primarily to bacterial infections and little work has been done on the relationship between iron and protein deficiency and infestations of the gut with nonbacterial parasites. Gastrointestinal helminthiasis is the commonest cause of iron deficiency anaemia when considered on a global basis and it has usually been assumed that the iron deficiency is secondary

Received for publication 28 September 1976 to the worm infestation. As protein and iron deficiency commonly coexist with heavy worm infestations, it may be that these nutrient deficiencies potentiate the infestation, thus explaining the lack of success of some worm eradication programmes.

It was therefore decided to investigate the association between iron and protein deficiency and gastrointestinal helminthiasis using an animal modelnamely, rats infected with the nematode Nippostrongylus brasiliensis. During the course of a primary infestation with this parasite, subcutaneously inoculated third stage larvae migrate from the skin and subcutis through the lungs to the oesophagus and on to the small intestine where they mature sexually and begin to produce eggs about five to six days after infestation. During the period six to 10 days, adult worms in the small intestine elicit a marked inflammatory reaction, particularly in the duodenum and jejunum. Between 10 and 16 days more than $95 \%$ of the worms are expelled from the gut by a complex multiphasic immune response (Kelly and Dineen, 1972). If there was an effect of iron and/or protein deficiency on the immune responses controlling worm expulsion, then this should be evident as a delay in natural worm rejection. 


\section{Methods}

PARASITE

The procedures for culture of $N$. brasiliensis, preparation and administration of infective larvae, and estimation of worm burdens have been described (Kelly and Dineen, 1972; Love et al., 1974).

\section{PREPARATION OF NUTRIENT DEFICIENT}

ANIMALS

Four week old Wistar rats were weaned onto a synthetic diet (Bolin et al., 1971). This diet in control animals consisted of $30 \%$ protein, $50 \%$ carbohydrate, $9.6 \%$ fat with vitamin and mineral supplements. Iron deficiency was produced by withdrawing iron from the diet and housing the animals in brass cages. Protein deficiency was produced by reducing the protein content of the diet to $10 \%$. Rats were infested with $N$. brasiliensis at the age of 10 weeks. Blood was collected for haemoglobin and serum albumin estimations at various times after infection (see experimental design and results).

STATISTICS

All data were transformed $\log 10(x+1)$ before analysis by Student's $t$ test (experiments 1, 3, and 4) or Duncan's (1955) New Multiple Range Test (experiment 2).

\section{ANTIBODY - MEDIATED DAMAGE TO}

N. brasiliensis

\section{Histopathology}

A $1 \mathrm{~cm}$ segment of upper jejunum was removed from a site $20 \mathrm{~cm}$ distal to the pylorus and then split. The two excised pieces of small intestine were then placed on dry cardboard strips and left overnight in Carnoy's fixative. Twelve to 24 hours later the intestinal strips were dehydrated, embedded in paraffin wax, and sectioned longitudinally. Sections were stained with either astra blue saffranin at $\mathrm{pH} 3$ or with chromotrope. Sections were later studied in a random blind fashion for evidence of histological damage. Evidence of antibody initiated damage to worms was assessed by light microscopy, according to the technique described by Ogilvie and Hockley (1968).

\section{Experimental design}

\section{EXPERIMENT 1}

Effect of iron deficiency on worm expulsion Forty-eight rats, divided into eight equal groups were infested with 1500 third stage larvae of $N$. brasiliensis. Rats in groups 1-4 were iron sufficient, and those in groups 5-8 were iron deficient. Animals were killed at nine, 15,21 , and 28 days after infestation for estimation of total worm counts, haemoglobin values, and for assessment of degree of antibody initiated damage to worms and histology of jejunal mucosa.

\section{EXPERIMENT 2}

\section{Effect of iron repletion on worm expulsion}

The experimental design was similar to that described above, except that there were three dietary groups, each of 24 animals - that is, iron sufficient, iron deficient, and iron replenished. In a preliminary study it had been found that haemoglobin levels in iron deficient animals returned to normal three to four weeks after intramuscular iron therapy (unpublished data). Hence, the time of iron replenishment was chosen to be two days before infection, based on the assumption that tissue iron stores would have returned to normal while haemoglobin values would not have changed, the animals remaining anaemic. Therefore, two days before primary infestation with $N$. brasiliensis, each animal in one of the two iron deficient groups was given $5 \mathrm{mg}$ iron dextran ${ }^{1}$ intramuscularly, this becoming the iron replenished group.

\section{EXPERIMENT 3}

\section{Effect of protein deficiency on worm expulsion}

The experimental design was similar to that described for experiment 1 , except that rats were given a primary infection of 1000 third stage larvae. There were two groups of 24 animals, one being protein deficient, the other protein sufficient.

\section{EXPERIMENT 4}

\section{Effect of iron and protein deficiency on worm expulsion}

The experimental design was similar to that for experiment 3 and consisted of two groups of animals, one being iron and protein sufficient, the other iron and protein deficient.

\section{Results}

\section{EXPERIMENT 1}

The results are presented in Table 1. There was significant delay in the expulsion of worms from iron deficient animals as evidenced by the highly significant number of $N$. brasiliensis remaining on days 15,21 , and 28 . On day 21 all but eight worms (99.2\% rejection) had been expelled from the iron IImferon, Fisons Pty Limited, North Sydney, Australia. 
sufficient group, while $16.5 \%$ of worms $\frac{(637-105}{637} \times \frac{100}{1}-$ Table 1) remained in the iron deficient group. In addition to the delay in expulsion, there was also a change in the distribution of the worms. In control animals, the infestation was confined to the duodenum and upper jejunum, whereas in the iron deficient animals worms were found throughout the small intestine.

The degree of antibody initiated damage to adult $N$. brasiliensis was similar in both iron sufficient and deficient rats at all times throughout the infection period. For example, the ratios of damaged to normal worms on days nine and 15 were: 30:70 and 82:18 respectively in iron sufficient animals, and $26: 74$ and $88: 12$ respectively in iron deficient animals. Throughout the course of infection, animals in the control group had mean haemoglobin values of $17 \cdot 2 \pm 0.7 \mathrm{~g} \%$, while the iron deficient animals had mean haemoglobin levels of $7.5 \pm 0.6 \mathrm{~g} \%$.

\section{EXPERIMENT 2}

These results again confirm that iron deficient animals have a significantly slower rate of worm expulsion when compared with iron sufficient controls (Table 2). For example, on day 21 only one worm was found in the iron sufficient group, there being 98 worms in the iron deficient animals and five worms in the iron replenished group. Animals in the iron replenished group behaved in a similar fashion to the iron sufficient controls even though their haemoglobin values had not returned to normal. The mean haemoglobin values were $16.6 \pm 1.5 \mathrm{~g} \%$ and $6.8 \pm 2.5 \%$ for animals in the iron sufficient and iron deficient groups respectively. In iron replenished rats haemoglobin values at days 15,21 , and 28 were $12.8 \pm 0.6 \mathrm{~g} \%, 11.7 \pm 0.5 \mathrm{~g} \%$ and $14.9 \pm 0.9 \mathrm{~g} \%$ respectively (Table 2 ).

\section{EXPERIMENT 3}

The results demonstrate a delay in expulsion of worms from protein deficient animals. The animals remain infested up to the completion of the experiment at day 49. Evidence of protein deficiency is shown by differences in body weight and mean serum albumin (Table 3 ).

\section{EXPERIMENT 4}

As can be seen from Table 4 there is a significant delay in worm expulsion from rats which are both iron and protein deficient. The worm burden was greater than that seen in the presence of iron deficiency alone or protein deficiency alone and thus the effect of combined iron and protein deficiency would appear to be additive.
Table 1 Effect of iron deficiency on expulsion of Nippostrongylus brasiliensis in rats given primary infection of 1500 third stage larvae

\begin{tabular}{lccl}
\hline $\begin{array}{l}\text { Day after } \\
\text { infection }\end{array}$ & $\begin{array}{l}\text { Group mean total worm counts } \\
\text { in small intestine } \pm S E\end{array}$ & $\begin{array}{l}\text { Significance of } \\
\text { difference between } \\
\text { group means for } \\
\text { total worm counts }\end{array}$ \\
\cline { 2 - 4 } & Controls & Iron deficient & $\begin{array}{l}\text { NS } \\
9\end{array}$ \\
\hline $656 \pm 49$ & $637 \pm 68$ & P $<0.05$ \\
21 & $41 \pm 18$ & $183 \pm 52$ & P $<0.05$ \\
28 & $8 \pm 6$ & $105 \pm 57$ & P $<0.05$ \\
\hline
\end{tabular}

*(Data transformed $\log _{10}(x+1)$ for analysis by Student's $t$ test).

Table 2 Effect of iron repletion on expulsion of $\mathrm{N}$. brasiliensis in rats given a primary infection of 1500 third stage larvae

\begin{tabular}{|c|c|c|c|}
\hline $\begin{array}{l}\text { Day after } \\
\text { infection }\end{array}$ & Group & $\begin{array}{l}\text { Mean } \\
\text { haemoglobin } \\
(g / d l)\end{array}$ & $\begin{array}{l}\text { Group mean } \\
\text { total worm counts } \\
\text { in small intestine } \\
\pm S E\end{array}$ \\
\hline \multirow[t]{3}{*}{9} & Fe sufficient & - & $459 \pm 101^{a}$ \\
\hline & Fe deficient & - & $498 \pm 57^{\circ}$ \\
\hline & Fe replenished & - & $600 \pm 82$ \\
\hline \multirow[t]{3}{*}{15} & Fe sufficient & $16.0 \pm 1.8$ & $9 \pm \quad 4^{\mathrm{a}}$ \\
\hline & Fe deficient & $6.0 \pm 0.3$ & $215 \pm 64^{b}$ \\
\hline & Fe replenished & $12 \cdot 8 \pm 2 \cdot 2$ & $18 \pm 11^{2}$ \\
\hline \multirow[t]{3}{*}{21} & Fe sufficient & $15 \cdot 5 \pm 2 \cdot 4$ & $1 \pm 3^{3}$ \\
\hline & Fe deficient & $6.9 \pm 0.5$ & $98 \pm 25^{b}$ \\
\hline & Fe replenished & $11 \cdot 7 \pm 1 \cdot 3$ & $5 \pm$ \\
\hline \multirow[t]{3}{*}{28} & Fe sufficient & $17.4 \pm 1.9$ & $1 \pm 5$ \\
\hline & Fe deficient & $8 \cdot 1 \pm 0.3$ & $89 \pm 38^{\mathrm{b}}$ \\
\hline & Fe replenished & $15.0 \pm 1.5$ & $6 \pm$ \\
\hline
\end{tabular}

* Data transformed $\log _{10}(x+1)$ for analysis by Duncan's New Multiple Range Test (1955). Means bearing the same superscript are not significantly different at the 5 percent level. Means bearing different superscripts are significantly different at the $5 \%$ level.

Table 3 The effect of protein deficiency on expulsion of $\mathrm{N}$. brasiliensis in rats given a primary infection of 1000 third stage larvae

\begin{tabular}{|c|c|c|c|}
\hline \multirow[t]{2}{*}{$\begin{array}{l}\text { Day after } \\
\text { infection }\end{array}$} & \multicolumn{2}{|c|}{$\begin{array}{l}\text { Group mean total worm counts* } \\
\text { in small intestine } \pm S E\end{array}$} & \multirow{2}{*}{$\begin{array}{l}\text { Significance of } \\
\text { difference } \\
\text { between group } \\
\text { means for total } \\
\text { worm counts }\end{array}$} \\
\hline & Control & Protein deficient & \\
\hline 9 & $401 \pm 48$ & $499 \pm 42$ & NS \\
\hline 15 & $9 \pm 25$ & $96 \pm 35$ & NS \\
\hline 21 & $3 \pm 2.5$ & $26 \pm 19$ & NS \\
\hline 28 & $0.6 \pm 1.4$ & $38 \pm 17.8$ & $P<0.001$ \\
\hline 35 & 0 & $34 \pm 12.4$ & $\mathbf{P}<0.001$ \\
\hline 42 & 0 & $27 \pm 11$ & $P<0.001$ \\
\hline 49 & 0 & \pm 7.5 & $P<0.001$ \\
\hline $\begin{array}{l}\text { Mean body } \\
\text { weight (g) }\end{array}$ & $230 \pm 11$ & $155 \pm 14$ & $P<0.05$ \\
\hline $\begin{array}{l}\text { Mean Hb } \\
(\mathrm{g} / \mathrm{dl})\end{array}$ & $15 \cdot 0 \pm 1 \cdot 5$ & $14 \cdot 7 \pm 1 \cdot 1$ & NS \\
\hline $\begin{array}{l}\text { Mean serum } \\
\text { albumin } \\
\text { (g/dl) }\end{array}$ & $2 \cdot 9$ & $2 \cdot 4$ & $P<0.05$ \\
\hline
\end{tabular}

*Data transformed $\log _{10}(x+1)$ for analysis by Student's $t$ test.

On assessing antibody damage to worms it was found that ratios of damaged to normal worms were comparable in both the control and iron/ protein deficient groups. 
Table 4 The effect of iron/protein deficiency on expulsion of $\mathrm{N}$. brasiliensis in rats given a primary infection of 1000 third stage larvae

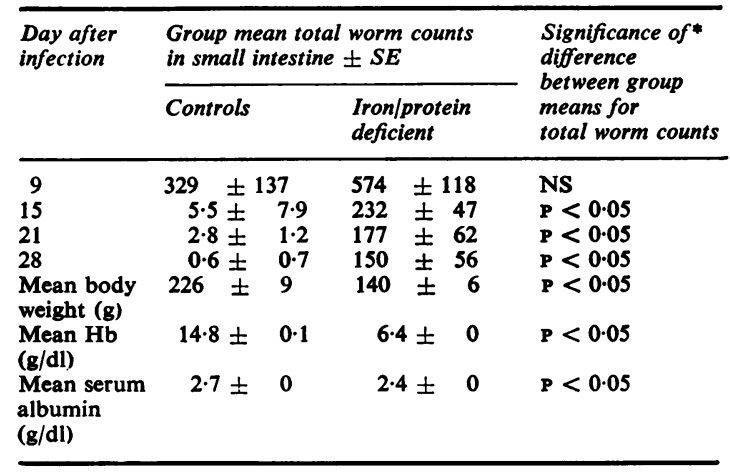

*Data transformed $\log _{10}(x+1)$ for analysis by Student's $t$ test.

\section{HISTOPATHOLOGY}

Animals in both control and iron deficient groups developed changes of partial villous atrophy in the presence of worm infestation. The mucosal changes returned to normal in both the control and iron repleted groups as $N$. brasiliensis was expelled. However, the mucosa remained abnormal with persisting partial villous atrophy in the iron and protein deficient groups. This was related to the continuing worm infestation.

\section{Discussion}

The mechanism of expulsion of adult worms in the small intestine has been extensively studied in the case of infection with $N$. brasiliensis in the rat. At the specific immunological level, both antibody and cell-mediated components have been implicated and, in addition, bone marrow cells and endogenous mediators of the inflammatory response may play crucial roles. Immune rejection of adult $N$. brasiliensis from the intestine of rats can be categorised into at least a three-step process. In the first step antibodies initiate morphological and biochemical damage to the worms (Ogilvie and Jones, 1968), which then become susceptible to the second and third steps for which sensitised lymphocytes (Kelly and Dineen, 1972) and a bone marrow derived component (probably of myeloid origin) are required (Dineen and Kelly, 1973; Kelly et al., 1973).

The rejection of $N$. brasiliensis adult worms is accompanied by an acute inflammatory response in the gastrointestinal tract. This would suggest that various mediators of inflammatory reactions, such as histamine, 5-hydroxytryptamine and prostaglandins may play important roles in worm expulsion. So far the evidence that a myeloid-amine response-that is, mast cells, eosinophils, histamine, 5-hydroxytryptamine-is involved is controversial (Kelly et al., 1974). Recent studies have suggested that prostaglandins, in particular $\mathrm{PGE}_{1}$ and $\mathrm{PGE}_{2}$, rather than amines are endogenous mediators of expulsion (Kelly et al., 1974). However, the precise nature and sequence of events linking immune lymphocytes, bone marrow cells, and prostaglandins in the mechanism of expulsion is unknown.

Using the rat $N$. brasiliensis system it has been shown that iron and protein deficiency potentiate worm infestation in the gut and in the case of iron deficiency this effect can be overcome by iron replenishment even though haemoglobin values did not return to normal, the animals remaining anaemic. The present results show that the antibody initiated damage to worms remains normal in both the iron and protein deficient animals and indirectly suggests that the defect in worm expulsion may occur at the immunologically non-specific third step involved in the synthesis, release and/or action of the nonspecific endogenous mediators of worm expulsion. Wells (1962) found significantly fewer eosinophils in the duodenal submucosa of protein deficient rats and also found the histamine content of the small intestine to be significantly higher during the latter stages of infection in these animals than in protein sufficient controls. Thus, protein deficiency may affect the myeloid-amine response. Further work is clearly needed to define the mechanism whereby helminth infections are potentiated by iron and protein deficiency and whether other deficiency states play a similar role.

Ferguson and Jarrett (1975) suggested that normal $T$ cell function was necessary for the production of the mucosal lesion of partial villous atrophy. The finding of similar degrees of partial villous atrophy in control and nutrient deficient animals in this present experiment would therefore suggest that $T$ cell function was normal, if the hypothesis of Ferguson and Jarrett is accepted. Their animals, however, had undergone thymectomy and been given a lethal dose of radiation before infestation with $N$. brasiliensis. It is therefore difficult to relate the results of this present experiment to that study. Furthermore, there is an increasing body of evidence in man showing impairment of the cell mediated immune system in the presence of both iron deficiency (Joynson et al., 1972; Chandra and Saraya, 1975), and protein deficiency (Smythe et al., 1971; Chandra, 1972; Neumann et al., 1975). The defect present in protein deficiency is reversible with adequate nutrition (Law et al., 1973).

It is of interest that the study by Neumann et al. (1975) in Ghana demonstrated depressed cell mediated immunity which was directly related to the 
severity of the protein calorie malnutrition, and this in turn was associated with an increased prevalence of bacterial infection. Furthermore there was a tenfold greater prevalence of Strongyloides stercoralis infestation of severely malnourished children, even though the infestation rate of other worms was comparable in the severely malnourished, moderately malnourished, and control groups.

If one can extrapolate from the results of the present study to the human situation there may be important therapeutic implications. Iron and protein deficiency may play an important role in the perpetuation of helminth infestations. Thus to be successful, antihelminth therapy should be accompanied by iron and protein supplementation.

We would like to thank Miss Glenda Walsh and $\mathrm{Mr} \mathrm{H}$. Whitlock for their technical assistance. This study was supported by a generous grant from Mr L. A. Scandrett and by a grant from the National Health and Medical Research Council of Australia.

\section{References}

Bolin, T. D., McKern, A., and Davis, A. E. (1971). The effect of diet on lactase activity in the rat. Gastroenterology, 60, 432-437.

Caroline, L., Rosner, R., and Kozinn, P. J. (1969). Elevated serum iron, low unbound transferrin and candidiasis in acute leukemia. Blood, 34, 441-451.

Chandra, R. K. (1972). Immunocompetence in undernutrition. Journal of Paediatrics, 81, 1194-1200.

Chandra, R. K., and Saraya, A. K. (1975). Impaired immunocompetence associated with iron deficiency. Journal of Paediatrics, 86, 899-902.

Dineen, J. K., and Kelly, J. D. (1973). Expulsion of Nippostrongylus brasiliensis from the intestine of the rat: the role of a cellular component derived from bone marrow. International Archives of Allergy and Applied Immunology. 45, 759-766.

Duncan, D. B. (1955). Multiple range and multiple F tests. Biometrics, 11, 1-42.

Ferguson, A., and Jarrett, E. E. E. (1975). Hypersensitivity reaction in the small intestine. 1 . Thymus dependence of experimental partial villous atrophy. Gut, 16, 114-117.

Fletcher, J., and Goldstein, E. (1970). The effect of parenteral iron preparations on experimental pyelonephritis. British
Journal of Experimental Pathology, 51, 280-285.

Joynson, D. H. M., Jacobs, A., Murray Walker, D., and Dolby, A. E. (1972). Defect of cell-mediated immunity in patients with iron deficiency anaemia. Lancet, 2, 10581059.

Kelly, J. D., and Dineen, J. K. (1972). The cellular transfer of immunity to Nippostrongylus brasiliensis in inbred rats (Lewis strain). Immunology, 22, 199-210.

Kelly, J. D., Dineen, J. K., Goodrich, B. S., and Smith, I. D. (1974). Expulsion of Nippostrongylus brasiliensis from the intestine of rats: the role of prostaglandins and pharmacologically active amines (histamine; 5 hydroxytryptamine) in worm expulsion. International Archives of Allergy and Applied Immunology, 47, 458-465.

Kelly, J. D., Dineen, J. K., and Love, R. J. (1973). Expulsion of Nippostrongylus brasiliensis from the intestine of the rat: evidence for the third component in the rejection mechanism. International Arcrives of Allergy and Applied Immunology, 45, 767-779.

Law, D. K., Dudrick, S. J., and Abdou, N. I. (1973). Immunocompetence of patients with protein-calorie malnutrition: The effects of nutritional repletion. Annals of Internal Medicine, 79, 545-550.

Love, R. J., Kelly, J. D., and Dineen, J. K. (1974). Nippostrongylus brasiliensis: effects of immunity on the preintestinal and intestinal larval stages of the parasite. International Journal for Parasitology, 4, 183-191.

Masawe, A. E., Muindi, J. M., and Swai, G. B. R. (1974). Infections in iron deficiency and other types of anaemia in the tropics. Lancet, 2, 314-317.

Neumann, C. G., Lawlor, G. J. Jr., Stiehm, E. R., Swendseid, M. E., Newton, C., Herbert, J., Ammann, A. J., and Jacob M. (1975). Immunologic responses in malnourished children. American Journal of Clinical Nutrition, 28, 89-104.

Ogilvie, B. M., and Hockley, D. J. (1968). Effects of immunity on Nippostrongylus brasiliensis adult worms: reversible and irreversible changes in infectivity, reproduction and morphology. Journal of Parasitology, 54, 1073-1084.

Oglivie, B. M., and Jones, V. E. (1968). Passive protection with cells or antiserum against Nippostrongylus brasiliensis in the rat. Parasitology, 58, 939-949.

Scrimshaw, N. S., Taylor, C. E., and Gordon, J. E. (1968). Interactions of nutrition and infection. Geneva World Health Organisation Monograph. No. 57. WHO: Geneva.

Smythe, P. M., Brereton-Stiles, G. G., Grace, H. J., Mafoyane, A., Schonland, M., Coovadia, H. M., Loening, W.E. K., Parent, M. A., and Vos, G. (1971). Thymolymphatic deficiency and depression of cell-mediated immunity in protein-calorie malnutrition. Lancet, 2, 939-944.

Wells, P. D. (1962). Mast cell, eosinophil and histamine levels in Nippostrongylus brasiliensis infected rats. Experimental Parasitology, 12, 82-101 